\title{
Synthesis, Characterization and Pharmacological Screening of Some Novel 2- substituted and $1(H)$-substituted Benzimidazole Derivatives as potent Anti-cancer agents
}

\author{
Pankaj S. Kore ${ }^{1}$, Santosh K. Singh ${ }^{2}$, Shrinivas K. Mohite ${ }^{3}$ \\ ${ }^{1,2}$ Suresh Gyan Vihar University Mahal, Jagatpura, Jaipur, Rajasthan, India- 302017 \\ ${ }^{3}$ Rajarambapu College of Pharmacy. Kasegaon, Dist. Sangli. Maharashtra, India- 415404 \\ *Corresponding author email-pkpankajpk3@gmail.com
}

\begin{abstract}
The most of drugs containing Benzimidazole ring is a prominent structural motif found in numerous therapeutically active compounds. Benzimidazole and its synthetic analogues have been found to exhibit industrial, agricultural and biological application such as antitubercular, anti-inflammatory, analgesic, anticancer, anticoagulant, as well as good antifungal and anti microbial activity. Recent advances in technology considers microwave irradiation energy as the most efficient means of heating reactions for chemical transformations that can be accomplished in a minutes. Microwave irradiation assists organic synthesis (MAOS) not only helps in implementing green chemistry but also led to progress in organic synthesis. We report pharmacological screening of some novel 2 substituted and 1(h)-substituted Benzimidazole derivatives.
\end{abstract}

Keywords: Benzimidazole, Synthesis, Anticancer, MTT assay, QSAR. 


\section{INTRODUCTION}

The benzofused nitrogen-containing heterocyclic compounds have a great importance in drug discovery, among them benzimidazole scaffold is of particular interest and has been categorized as a privileged scaffold.[1] The benzimidazole moiety is structurally correlated to the purine bases and is profusely found in a variety of natural products including vitamin B12.2 Several benzimidazole derivatives exhibit diversified pharmaceutical properties such as antimicrobial, [3] anticancer, [4] antiviral, [5]antihelmintic,[6] antioxidant,[7] antiulcer,[8] antihypertensive [9] and antitubercular.[10] For example, benzimidazoloquinolinone conjugate "Dovitinib (I)", a potent EGFR-3 inhibitor, is currently in phase-III clinical trials for the treatment of metastatic renal cell cancer, [11] the thiazolobenzimidazole derivative "Tiabendazole (II)" acts as an anthelmintic drug, [12] and Pimobendan (III) has been used as a vasodilator for the management of heart failure in dogs. Additionally, the bisbenzimidazole containing Hoechst stain (IV) is widely used to stain DNA in fluorescence microscopy, immune histo chemistry, and flow cytometry. The most prominent benzimidazole compound in nature is $\mathrm{N}$ riosyldimethylbenzimidazole, which serves as an axial ligand for cobalt in vitamin B12. The benzimidazole and its derivatives play a very important role as therapeutic agent e.g. antiulcer and anthelmintic drugs. Antiulcer agents and medications for acid peptic disease are commonly used drugs that rarely cause liver injury. Most agents act by inhibition of gastric acid production, neutralization of acid or protection of the gastrointestinal mucosa from acid injury. These agents are used for both prevention and therapy of duodenal and gastric ulcer disease as well as to alleviate acid reflux, esophagi is and minor upper intestinal discomforts. The most commonly used antiulcer agents are antacids such as aluminum or magnesium hydroxide (Maalox, Mylanta and many others) and calcium carbonate (Tums, Rolaids and others). Antacids are minimally absorbed and have no known adverse effects on the liver. Antacid use may cause a minor rise in urinary $\mathrm{pH}$ and rarely the calcium salts cause hypercalcemia. Other antiulcer drugs include mucosal protective agents such as sucralfate and prostaglandin analogues (misoprostol). Sucralfate (Carafate and others) is a sulfated polysaccharide that becomes a viscous polymer adhering to ulcers in mucosal surfaces and aiding in healing. Carafate is not absorbed and has not been linked to liver injury. Misoprostol is a synthetic prostaglandin E1 analogue that inhibits acid secretion and aids in ulcer healing. Misoprostol is absorbed systemically, but has not been linked to liver injury, probably because it's other side effects and 
need for four times daily dosing limit the duration and degree of exposure. The major, most potent and effective antiulcer medications are the selective histamine type 2 receptor blockers (H2 blockers) and the proton pump inhibitors (PPIs). Both classes of antiulcer medications block the pathways of acid production or secretion, decreasing gastric acidity, improving symptoms and aiding in healing of acid-peptic diseases. These are some of the most commonly used drugs in medicine and are generally well tolerated and rarely result in serious adverse events. Nevertheless, both of these classes of agents have been linked to rare instances of acute liver injury.

\section{MATERIALS AND METHODS}

\subsection{Chemistry}

Starting materials were purchased from commercial sources and were used without further purification. Solvents were dried according to standard procedure. The reaction progress was monitored by thin layer chromatography (TLC) on aluminum sheet obtained from Merck. Silica gel 60-120 mess was used for column chromatography. Melting points were recorded on Thermomik Campbell Melting Point apparatus having an oil bath system and were uncorrected. IR spectrum was recorded on FTIR (Perkin Elmer Spectrum RX1) by preparing KBrpellets.All ${ }^{1} \mathrm{H}$ and ${ }^{13} \mathrm{C}$ NMR was recorded on $400 \mathrm{MHz}$ Varian Mercury NMR instrument. All NMR spectra were recorded in $\mathrm{CDCl}_{3}$ or DMSO- $\mathrm{d}_{6}$ solutions using TMS as an internal standard. Chemical shifts are reported in ppm $(\delta)$. Mass spectra were recorded on Agilent 7820A GC systems (SIS-Direct insertion probe) and LC-MS TOF 6520A.

\subsubsection{Synthesis of benzimidazole-2-carboxylate derivatives (3a-e)}

Different substituted/ unsubsituted1, 2-diamino-benzene $(10 \mathrm{mmol})$ and diethyl oxalate (12 mmol) were stirred in $100 \mathrm{~mL}$ of EtOH. The reaction mixture was stirred for $4 \mathrm{~h}$ at reflux and the completion of the reaction was monitored on Thin Layer Chromatography (TLC). Finally, the reaction mixture was cooled, diluted with $200 \mathrm{~mL}$ of ice cold water and solid was filtered. The solid organic precipitate (55-85\% yield) was dried and this crude material was taken to the next step.

\subsubsection{Synthesis of benzimidazole-2-carbohydrazide derivatives (4a-d)}


The starting material 3a $(10 \mathrm{mmol})$ was taken in $50 \mathrm{~mL}$ ethanol solvent and allowed to stir for 10 minutes. A $6 \mathrm{~mL}$ mixture of $\mathrm{H}_{2} \mathrm{NNH}_{2} \cdot \mathrm{H}_{2} \mathrm{O}$ and $\mathrm{HCl}(1: 1)$ was prepared at 5 to $10^{\circ} \mathrm{C}$. This mixture was transferred to the RBF containing 3a solution at room temperature. The reaction mixture was refluxed for $4 \mathrm{~h}$. Progress of the reaction was monitored on TLC and after completion, the reaction mixture was poured on the ice water to get solid compound. After filtration and drying of the crude material (60-70\% yield), it was taken to the next step.

\subsubsection{Synthesis of 4-phenoxybenzaldehyde derivatives (7a-f)}

A mixture of phenolic compound $5 \mathbf{a}(19.35 \mathrm{mmol})$ and dried $\mathrm{K}_{2} \mathrm{CO}_{3}(58 \mathrm{mmol})$ was added to 30 $\mathrm{mL}$ DMSO solvent. This mixture was stirred for one hour at room temperature.4Fluorobenzaldehyde $6(16.13 \mathrm{mmol})$ was added to the above stirring solution and the reaction mixture was heated at $90^{\circ} \mathrm{C}$ for $16 \mathrm{~h}$. After completion of the reaction, the mixture was poured on crushed ice and extracted with ethyl acetate $(50 \mathrm{~mL} \times 3$ times). The organic layer was dried over sodium sulphate and then evaporated to get crude product. Pure product, pale yellow solid (65$75 \%$ yield) was obtained by silica gel column chromatography using hexane as solvent.

\subsubsection{General procedure for the synthesis of $\mathrm{N}^{\prime}$-(4-phenoxybenzylidene)- $1 H$-benzimidazole- 2-carbohydrazide derivatives (8a-j)}

Benzimidazole-2-carbohydrazide derivative $(0.1 \mathrm{~g}, 0.57 \mathrm{mmol})$ were added to $10 \mathrm{~mL} 2$ necked round bottom flask containing 4-phenoxybenzaldehyde derivatives $(0.51 \mathrm{mmol})$ and $0.5 \mathrm{~mL}$ acetic acid. Finally, the reaction mixture was stirred for $1-3 \mathrm{~h}$ at $80^{\circ} \mathrm{C}$. Progress of the reaction was monitored on TLC. After completion of reaction, precipitate was formed which on cooling and after filtration gave the desired product in $80-90 \%$ yield. 
Ste.1 Synthesis of benzimidazole-2-carboxylate derivatives<smiles>[R]c1ccc(N)c(N)c1</smiles>

benzene-1,2-diamine<smiles>CCOC(=O)C(=O)OCC</smiles>

diethyl ethanedioate<smiles>CCCC</smiles><smiles>[R]C=CCN</smiles>

b $(3 a-e)$<smiles>[R]c1ccc2nc(C(=O)NN)[nH]c2c1</smiles>

Step 2. Synthesis of benzimidazole-2-carbohydrazide derivatives<smiles>Oc1ccccc1</smiles><smiles>O=Cc1ccc(F)cc1</smiles>

phenol 4-fluorobenzaldehyde

$\mathrm{OHC}$<smiles>Cc1ccc(Oc2ccccc2)cc1</smiles>

4-phenoxybenzaldehyde

Step 3. Synthesis of 4-phenoxybenzaldehyde derivatives<smiles>[R]c1ccc2nc(C(=O)NN)[nH]c2c1</smiles><smiles>O=Cc1ccc(Oc2ccccc2)cc1</smiles>

$d \downarrow$

4-phenoxybenzaldehyde<smiles>[R]c1ccc2nc(C(=O)N/N=C/c3ccc(Oc4ccccc4)cc3)[nH]c2c1</smiles>
a) $\mathrm{EtOH}$, Reflux 6h
b) $\mathrm{H}_{2} \mathrm{NNH}_{2} . \mathrm{H}_{2} \mathrm{O}$ : $\mathrm{HCl}(1: 1)$ ethtlene glycol reflux
c) $\mathrm{K}_{2} \mathrm{CO}_{3}$, DMSO $90^{\circ} \mathrm{C} 16 \mathrm{hr}$.
d) $\mathrm{EtOH}$, Acetic acid, reflux $2 \mathrm{hr}$

Figure 1. Scheme for synthesis of 4-phenoxybenzaldehyde 


\subsection{Analytical Data of the 4-phenoxybenzaldehyde}

\section{(E)-N'-(4-(2-chlorophenoxy) benzylidene)-1H-benzo[d]imidazole-2-carbohydrazide (8a)}

To the stirred solution of $1 \mathrm{H}$-benzo[d]imidazole-2-carbohydrazide4a(0.1g, $0.57 \mathrm{mmol})$ in EtOH $(10 \mathrm{~mL})$ and $\mathrm{AcOH}(0.1 \mathrm{~mL}, 1.6 \mathrm{mmol}), 4$-(2-chlorophenoxy) benzaldehyde $7 \mathbf{a}(0.2 \mathrm{~g}, 0.51 \mathrm{mmol})$ was added. The reaction mixture was stirred for $3 \mathrm{~h}$ at $80^{\circ} \mathrm{C}$. The reaction completion was monitored by TLC (50\% EtOAc: Hexane). After consumption of $\mathbf{4 a}$, the solvent of reaction mixture was evaporated under reduced pressure and then quenched with an ice cold water. Precipitate formed is filtered off, washed, crystallized with EtOH and dried to afford 0.172gof 8a.Buff white solid; 238-240 C; yield 78\%; IR spectra (KBr): 3451, 3191, 3076, 2951, 1619, 1578, 1503, 1442, 1260, 1123, 748 $\mathrm{cm}^{-1} ;{ }^{1} \mathrm{H}$ NMR (300 MHz, $\left.\mathrm{CDCl}_{3}\right): \delta(\mathrm{ppm}) 8.73(\mathrm{~s}, 1 \mathrm{H},-$ $\mathrm{N}=\underline{\mathrm{CH}}-\mathrm{Ar}), 7.92-7.09(\mathrm{~m}, 12 \mathrm{H}, \mathrm{Ar}-\mathrm{H})$; LC-MS: $392[\mathrm{M}+1]^{+}$; Elemental Analysis for $\mathrm{C}_{21} \mathrm{H}_{15} \mathrm{ClN}_{4} \mathrm{O}_{2}$ (390.82): C, 64.54; H, 3.87; N, 14.34 found: C, 64.04; H, 3.62; N, 13.87

\section{(E)-N'-(4-(4-chlorophenoxy) benzylidene)-1H-benzo[d]imidazole-2-arbohydrazide (8b)}

To the stirred solution of $1 \mathrm{H}$-benzo[d]imidazole-2-carbohydrazide $4 \mathbf{a}(0.1 \mathrm{~g}, 0.57 \mathrm{mmol})$ in EtOH $(10 \mathrm{~mL})$ and $\mathrm{AcOH}(0.1 \mathrm{~mL}, 1.6 \mathrm{mmol}), 4-(4-c h l o r o p h e n o x y)$ benzaldehyde $7 \mathbf{b}$ (0.2g, 0.51 mmol) was added. The reaction mixture was stirred for $3 \mathrm{~h}$ at $80^{\circ} \mathrm{C}$. The reaction completion was monitored by TLC (50 \% EtOAc: Hexane). After consumption of 4a, the solvent of reaction mixture was evaporated under reduced pressure and then quenched with ice cold water. Precipitate formed is filtered off, washed, crystallized with EtOH and dried to afford $0.168 \mathrm{~g}$ of 8b. Buff white solid; 224-226 ${ }^{\circ} \mathrm{C}$; yield 76\%; IR spectra (KBr): 3422, 3182, 3066, 2951, 1615 , $1575,1503,1482,1236,748 \mathrm{~cm}^{-1} ;{ }^{1} \mathrm{H} \mathrm{NMR}\left(300 \mathrm{MHz}, \mathrm{CDCl}_{3}\right): \delta(\mathrm{ppm}) 8.71(\mathrm{~s}, 1 \mathrm{H},-\mathrm{N}=\underline{\mathrm{CH}}-$ Ar), 7.95-7.06 (m, 12H, Ar-H); LC-MS: $391.89[\mathrm{M}+1]^{+}$; Elemental Analysis for $\mathrm{C}_{21} \mathrm{H}_{15} \mathrm{ClN}_{4} \mathrm{O}_{2}$ (390.82): C, 64.54; H, 3.87; N, 14.34 found: C, 64.14; H, 3.57; N, 14.01.

(E)-N'-(4-(4-chloro-3-methylphenoxy) benzylidene)-1H-benzo[d]imidazole-2-carbohydrazide (8c)

To the stirred solution of $1 \mathrm{H}$-benzo[d]imidazole-2-carbohydrazide $4 \mathbf{a}(0.1 \mathrm{~g}, 0.57 \mathrm{mmol})$ in EtOH $(10 \mathrm{~mL})$ and $\mathrm{AcOH}(0.1 \mathrm{~mL}, 1.6 \mathrm{mmol}), 4$-(4-chloro-3-methylphenoxy)benzaldehyde7c $(0.13 \mathrm{~g}$, $0.51 \mathrm{mmol}$ ) was added. The reaction mixture was stirred for $3 \mathrm{~h}$ at $80^{\circ} \mathrm{C}$. The reaction 
completion was monitored by TLC (50\% EtOAc: Hexane). After consumption of $\mathbf{4 a}$, the solvent of reaction mixture was evaporated under reduced pressure and then quenched with an ice cold water. Precipitate formed is filtered off, washed, crystallized with EtOH and dried to afford 0.149 g of 8c.Buff white solid; 232-234 ${ }^{\circ} \mathrm{C}$; yield $68 \%$; IR spectra (KBr): 3413, 3172, 3076, $2883,1629,1595,1490,1445,1267,1128,623 \mathrm{~cm}^{-1} ;{ }^{1} \mathrm{H}$ NMR $\left(300 \mathrm{MHz}, \mathrm{CDCl}_{3}\right): \delta(\mathrm{ppm}) 8.54$ $(\mathrm{s}, 1 \mathrm{H},-\mathrm{N}=\underline{\mathrm{CH}}-\mathrm{Ar}), 7.88-6.92(\mathrm{~m}, 11 \mathrm{H}, \mathrm{Ar}-\mathrm{H}), 2.41\left(\mathrm{~s}, 3 \mathrm{H},-\mathrm{CH}_{3}\right) ; \mathrm{LC}-\mathrm{MS}: 405.84[\mathrm{M}+1]^{+}$; Elemental Analysis for $\mathrm{C}_{22} \mathrm{H}_{17} \mathrm{ClN}_{4} \mathrm{O}_{2}$ (404.85): C, 65.27; H, 4.23; N, 13.84 found: $\mathrm{C}, 65.04 ; \mathrm{H}$, $3.95 ; \mathrm{N}, 13.42$.

\section{(E)-N'-(4-(2, 4-dichlorophenoxy) benzylidene)-1H-benzo[d]imidazole-2-carbohydrazide (8d)}

To the stirred solution of $1 \mathrm{H}$-benzo[d]imidazole-2-carbohydrazide4a( $0.1 \mathrm{~g}, 0.57 \mathrm{mmol})$ in $\mathrm{EtOH}$ $(10 \mathrm{~mL})$ and $\mathrm{AcOH}(0.1 \mathrm{~mL}, 1.6 \mathrm{mmol}), 4-(2$, 4-dichlorophenoxy)benzaldehyde7d $(0.14 \mathrm{~g}, 0.51$ mmol) was added. The reaction mixture was stirred for $3 \mathrm{~h}$ at $80^{\circ} \mathrm{C}$. The reaction completion was monitored by TLC (50\% EtOAc: Hexane). After consumption of $\mathbf{4 a}$, the solvent of reaction mixture was evaporated under reduced pressure and then quenched with ice cold water. Precipitate formed is filtered off, washed, crystallized with EtOH and dried to afford $0.173 \mathrm{~g}$ of 8d.Buff white solid; $235-237^{\circ} \mathrm{C}$; yield $72 \%$; IR spectra (KBr): 3422, 3182, 3066, 2951, 1625 , $1575,1503,1482,1236,748 \mathrm{~cm}^{-1} ;{ }^{1} \mathrm{H}$ NMR $\left(300 \mathrm{MHz}, \mathrm{CDCl}_{3}\right): \delta(\mathrm{ppm}) 8.68(\mathrm{~s}, 1 \mathrm{H},-\mathrm{N}=\underline{\mathrm{CH}}-$ Ar), 7.95-7.06 (m, 11H, Ar-H); LC-MS: $426.2[\mathrm{M}+1]^{+}$; Elemental Analysis for $\mathrm{C}_{21} \mathrm{H}_{14} \mathrm{Cl}_{2} \mathrm{~N}_{4} \mathrm{O}_{2}$ (425.27): C, 59.31; H, 3.32; N, 13.17 found: C, 58.91; H, 3.02; N, 12.94.

\section{(E)-N'-(4-(3,5-dichlorophenoxy)benzylidene)-1H-benzo[d]imidazole-2-carbohydrazide (8e)}

To the stirred solution of $1 \mathrm{H}$-benzo[d]imidazole-2-carbohydrazide4a(0.1g, $0.57 \mathrm{mmol})$ in EtOH $(10 \mathrm{~mL})$ and $\mathrm{AcOH}(0.1 \mathrm{~mL}, 1.6 \mathrm{mmol}), 4$-(3,5-dichlorophenoxy)benzaldehyde7e $(0.14 \mathrm{~g}, 0.51$ mmol) was added. The reaction mixture was stirred for $3 \mathrm{~h}$ at $80{ }^{\circ} \mathrm{C}$. The reaction completion was monitored by TLC (50\% EtOAc: Hexane). After consumption of 4a, the solvent of reaction mixture was evaporated under reduced pressure and then quenched with ice cold water. Precipitate formed is filtered off, washed, crystallized with $\mathrm{EtOH}$ and dried to afford $0.166 \mathrm{~g}$ of 8e.Buff white solid; 234-236 ${ }^{\circ} \mathrm{C}$; yield 69 \%; IR spectra (KBr): 3441, 3134, 3047, 2941, 2854 , $1611,1560,1502,1448,1251,1127 \mathrm{~cm}^{-1} ;{ }^{1} \mathrm{H}$ NMR $\left(300 \mathrm{MHz}, \mathrm{CDCl}_{3}\right): \delta 8.56(\mathrm{~s}, 1 \mathrm{H},-\mathrm{N}=\underline{\mathrm{CH}}-$ 
Ar), (ppm) 8.02-6.89 (m, 11H, Ar-H); LC-MS: $425.8[\mathrm{M}+1]^{+}$; Elemental Analysis for $\mathrm{C}_{21} \mathrm{H}_{14} \mathrm{Cl}_{2} \mathrm{~N}_{4} \mathrm{O}_{2}$ (425.27): C, 59.31; H, 3.32; N, 13.17 found: $\mathrm{C}, 58.91 ; \mathrm{H}, 3.02 ; \mathrm{N}, 13.10$.

(E)-N'-(4-(4-methoxyphenoxy) benzylidene)-1H-benzo[d]imidazole-2-carbohydrazide (8f)

To the stirred solution of $1 \mathrm{H}$-benzo[d]imidazole-2-carbohydrazide4a( $0.1 \mathrm{~g}, 0.57 \mathrm{mmol})$ in EtOH $(10 \mathrm{~mL})$ and $\mathrm{AcOH}(0.1 \mathrm{~mL}, 1.6 \mathrm{mmol}), 4-(4-m e t h o x y p h e n o x y)$ benzaldehyde $7 \mathrm{f}(0.12 \mathrm{~g}, 0.51$ mmol) was added. The reaction mixture was stirred for $3 \mathrm{~h}$ at $80^{\circ} \mathrm{C}$. The reaction completion was monitored by TLC (50\% EtOAc: Hexane). After consumption of 4a, the solvent of reaction mixture was evaporated under reduced pressure and then quenched with ice cold water. Precipitate formed is filtered off, washed, crystallized with EtOH and dried to afford $0.175 \mathrm{~g}$ of 8f.Buff white solid; $222-224{ }^{\circ} \mathrm{C}$; yield $80 \%$; IR spectra (KBr): 3432, 3193, 3085, 2989, 1627 , 1587, 1465, 1364, 1250, $1127 \mathrm{~cm}^{-1}$; ${ }^{1} \mathrm{H}$ NMR $\left(300 \mathrm{MHz}, \mathrm{CDCl}_{3}\right): \delta(\mathrm{ppm}) 8.64(\mathrm{~s}, 1 \mathrm{H},-\mathrm{N}=\underline{\mathrm{CH}}-$ Ar), 7.98-7.08 (m,12H, Ar-H), $3.84\left(\mathrm{~s}, 3 \mathrm{H},-\mathrm{OCH}_{3}\right)$; LC-MS: $386.4[\mathrm{M}+1]^{+}$; Elemental Analysis for $\mathrm{C}_{22} \mathrm{H}_{18} \mathrm{~N}_{4} \mathrm{O}_{3}(386.40)$ : $\mathrm{C}, 68.38 ; \mathrm{H}, 4.70 ; \mathrm{N}, 14.50$ found: $\mathrm{C}, 68.13 ; \mathrm{H}, 4.35 ; \mathrm{N}, 14.10$.

\section{(E)-N'-(4-(naphthalen-1-yloxy) benzylidene)-1H-benzo[d]imidazole-2-carbohydrazide (8g)}

To the stirred solution of $1 \mathrm{H}-$-benzo[d]imidazole-2-carbohydrazide4a( $0.1 \mathrm{~g}, 0.57 \mathrm{mmol})$ in EtOH $(10 \mathrm{~mL})$ and $\mathrm{AcOH}(0.1 \mathrm{~mL}, 1.6 \mathrm{mmol}), 4$-(naphthalen-1-yloxy)benzaldehyde7g $(0.13 \mathrm{~g}, 0.51$ $\mathrm{mmol}$ ) was added. The reaction mixture was stirred for $3 \mathrm{~h}$ at $80^{\circ} \mathrm{C}$. The reaction completion was monitored by TLC (50\% EtOAc: Hexane). After consumption of $\mathbf{4 a}$, the solvent of reaction mixture was evaporated under reduced pressure and then quenched with ice cold water. Precipitate formed is filtered off, washed, crystallized with $\mathrm{EtOH}$ and dried to afford $0.152 \mathrm{~g}$ of 8g.Buff white solid; $221-223{ }^{\circ} \mathrm{C}$; yield 66\%; IR spectra (KBr): 3442, 3182, 3067, 2955, 1620, $1565,1490,1434,1280,1128,748 \mathrm{~cm}^{-1} ;{ }^{1} \mathrm{H}$ NMR $\left(300 \mathrm{MHz}, \mathrm{CDCl}_{3}\right): \delta(\mathrm{ppm}) 8.46(\mathrm{~s}, 1 \mathrm{H},-$ $\mathrm{N}=\underline{\mathrm{CH}}-\mathrm{Ar}), 8.25-7.26(\mathrm{~m}, 15 \mathrm{H}, \mathrm{Ar}-\mathrm{H})$; LC-MS: $407.2[\mathrm{M}+1]^{+}$; Elemental Analysis for $\mathrm{C}_{25} \mathrm{H}_{18} \mathrm{~N}_{4} \mathrm{O}_{2}$ (406.66): C, 73.88; H, 4.46; N, 13.78 found: C, 73.35; H, 4.22; N, 13.47.

(E)-N'-(4-(2-chlorophenoxy) benzylidene)-6-methyl-1H-benzo[d]imidazole-2-carbohydrazide (8h)

To the stirred solution of 6-methyl-1H-benzo[d]imidazole-2-carbohydrazide $4 \mathbf{b}(0.1 \mathrm{~g}, 0.53 \mathrm{mmol})$ in $\mathrm{EtOH}(10 \mathrm{~mL})$ and $\mathrm{AcOH}(0.1 \mathrm{~mL}, 1.6 \mathrm{mmol}), 4-(2$-chlorophenoxy)benzaldehyde7a $(0.11 \mathrm{~g}$, 
$0.48 \mathrm{mmol}$ ) was added. The reaction mixture was stirred for $3 \mathrm{~h}$ at $80^{\circ} \mathrm{C}$. The reaction completion was monitored by TLC (50 \% EtOAc: Hexane). After consumption of $\mathbf{4 b}$, the solvent of reaction mixture was evaporated under reduced pressure and then quenched with ice cold water. Precipitate formed is filtered off, washed, crystallized with EtOH and dried to afford 0.166 g of 8h.Buff white solid; 227-229 ${ }^{\circ} \mathrm{C}$; yield 78\%; IR spectra (KBr): 3451, 3191, 3076, 2951, 1618, 1578, 1503, 1442, 1260, 1123, 748 $\mathrm{cm}^{-1} ;{ }^{1} \mathrm{H}$ NMR (300 MHz, $\left.\mathrm{CDCl}_{3}\right): \delta$ (ppm) 8.73

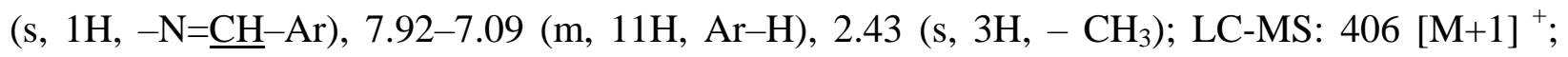
Elemental Analysis for $\mathrm{C}_{22} \mathrm{H}_{17} \mathrm{ClN}_{4} \mathrm{O}_{2}$ (404.85): C, 65.27; H, 4.23; N, 13.84 found: $\mathrm{C}, 65.07$; $\mathrm{H}$, $4.12 ; \mathrm{N}, 13.77$

\section{(E)-N'-(4-(4-chlorophenoxy)benzylidene)-6-methyl-1H-benzo[d]imidazole-2carbohydrazide(8i)}

To the stirred solution of 6-methyl-1H-benzo[d]imidazole-2-carbohydrazide $4 \mathbf{b}(0.1 \mathrm{~g}, 0.53 \mathrm{mmol})$ in $\mathrm{EtOH}(10 \mathrm{~mL})$ and $\mathrm{AcOH}(0.1 \mathrm{~mL}, 1.6 \mathrm{mmol}), 4$-(4-chlorophenoxy)benzaldehyde7b $(0.11 \mathrm{~g}$, $0.48 \mathrm{mmol}$ ) was added. The reaction mixture was stirred for $3 \mathrm{~h}$ at $80^{\circ} \mathrm{C}$. The reaction completion was monitored by TLC (50 \% EtOAc: Hexane). After consumption of $\mathbf{4 b}$, the solvent of reaction mixture was evaporated under reduced pressure and then quenched with ice cold water. Precipitate formed is filtered off, washed, crystallized with EtOH and dried to afford 0.149 g of 8i.Buff white solid; 234-236 ${ }^{\circ} \mathrm{C}$; yield 70\%; IR spectra (KBr): 3422, 3182, 3066, 2951, 1621, 1575, 1503, 1482, 1236, 748 $\mathrm{cm}^{-1} ;{ }^{1} \mathrm{H} \mathrm{NMR}\left(300 \mathrm{MHz}, \mathrm{CDCl}_{3}\right): \delta(\mathrm{ppm}) 8.72(\mathrm{~s}, 1 \mathrm{H}$, $-\mathrm{N}=\underline{\mathrm{CH}}-\mathrm{Ar}), 7.95-7.06(\mathrm{~m}, 11 \mathrm{H}, \mathrm{Ar}-\mathrm{H}), 2.43\left(\mathrm{~s}, 3 \mathrm{H},-\mathrm{CH}_{3}\right)$; LC-MS: $406[\mathrm{M}+1]^{+}$; Elemental Analysis for $\mathrm{C}_{22} \mathrm{H}_{17} \mathrm{ClN}_{4} \mathrm{O}_{2}$ (404.85): C, 65.27; H, 4.23; N, 13.84 found: $\mathrm{C}, 65.12 ; \mathrm{H}, 4.03 ; \mathrm{N}$, 13.63

\section{(E)-N'-(4-(2,4-dichlorophenoxy)benzylidene)-6-methyl-1H-benzo[d]imidazole-2}

carbohydrazide $(\mathbf{8 j})$

To the stirred solution of 6-methyl-1H-benzo[d]imidazole-2-carbohydrazide $4 \mathbf{b}(0.1 \mathrm{~g}, 0.53 \mathrm{mmol})$ in $\mathrm{EtOH}(10 \mathrm{~mL})$ and $\mathrm{AcOH}(0.1 \mathrm{~mL}, 1.6 \mathrm{mmol}), 4-(2,4$-dichlorophenoxy)benzaldehyde $7 \mathrm{c}(0.13 \mathrm{~g}$, $0.48 \mathrm{mmol}$ ) was added. The reaction mixture was stirred for $3 \mathrm{~h}$ at $80^{\circ} \mathrm{C}$. The reaction completion was monitored by TLC (50\% EtOAc: Hexane). After consumption of $\mathbf{4 b}$, the solvent of reaction mixture was evaporated under reduced pressure and then quenched with ice cold water. Precipitate formed is filtered off, washed, crystallized with EtOH and dried to afford 
$0.161 \mathrm{~g}$ of $\mathbf{8 j}$.Buff white solid; $229-231^{\circ} \mathrm{C}$; yield $70 \%$; IR spectra (KBr): $3441,3210,3085$, $2970,1625,1585,1506,1460,1261,1133,711 \mathrm{~cm}^{-1} ;{ }^{1} \mathrm{H}$ NMR $\left(300 \mathrm{MHz}, \mathrm{CDCl}_{3}\right): \delta(\mathrm{ppm}) 8.70$ (s, 1H, -N=CH$-\mathrm{Ar}), 7.94-7.04(\mathrm{~m}, 10 \mathrm{H}, \mathrm{Ar}-\mathrm{H}), 2.43$ (s, 3H, $\left.-\mathrm{CH}_{3}\right)$; LC-MS: $439[\mathrm{M}+1]^{+;}$ Elemental Analysis for $\mathrm{C}_{22} \mathrm{H}_{16} \mathrm{Cl}_{2} \mathrm{~N}_{4} \mathrm{O}_{2}$ (439.29): $\mathrm{C}, 60.15 ; \mathrm{H}, 3.67 ; \mathrm{N}, 12.75$ found: $\mathrm{C}, 59.85 ; \mathrm{H}$, $3.51 ; \mathrm{N}, 12.67$

\subsection{SAR of N'-(4-aryloxybenzylidene)-1H-benzimidazole-2-carbohydrazide derivatives}

From the biological screening of no substituted, alkyl, aroyl, nitro or halogen substituted derivatives of benzimidazole, it was found that benzimidazole derivative with alkyl (methyl) substitution shows better activity than the aroyl (benzoyl), nitro or halogen (chloro) substitution. Methyl substituted benzimidazole derivatives $\mathbf{8 h}-\mathbf{j}$ shown the activity range from 1.5 to 12.5 $\mu \mathrm{g} / \mathrm{mL}$, Introduction of electron donating (methyl) had a detrimental effect on the inhibitory activity compared to 8a-e.Replacement of sulphur atom in the benzothiazole ring by $-\mathrm{NH}$ (isostere of sulphur atom) and insertion of carbonyl group in the final designed molecule may be responsible for enhanced activity.

\subsection{Anticancer Activity:}

\section{MTT Assay}

Cells were incubated at a concentration of $1 \times 10^{4}$ cells $/ \mathrm{ml}$ in culture medium for $24 \mathrm{~h}$ at $37^{\circ} \mathrm{C}$ and $5 \% \mathrm{CO}_{2}$.Cells were seeded at a concentration $(70 \mu \mathrm{l}) 10^{4}$ cells/well in $100 \mu \mathrm{l}$ culture medium and $100 \mu \mathrm{l}$ herbal extracts into micro plates respectively (tissue culture grade, and 96 wells). Control wells were incubated with DMSO (0.2\% in PBS) and cell line. All samples were incubated in triplicate. Controls were maintained to determine the control cell survival and the percentage of live cells after culture. Cell cultures were incubated for $24 \mathrm{~h}$ at $37^{\circ} \mathrm{C}$ and $5 \% \mathrm{CO}_{2}$ in $\mathrm{CO}_{2}$ incubator. After incubation, the medium was completely removed and Added $20 \mu \mathrm{l}$ of MTT reagent $\left(5 \mathrm{mg} / \mathrm{min}\right.$ PBS). After addition of MTT, cells incubated for $4 \mathrm{hrs}$ at $37^{\circ} \mathrm{C}$ in $\mathrm{CO}_{2}$ incubator. Observed the wells for formazan crystal formation under microscope. The yellowish MTT was reduced to dark colouredformazan by viable cells only. After removing the medium 
completely. Added $200 \mu$ lof DMSO (kept for $10 \mathrm{~min}$ ) and incubate at $37^{\circ} \mathrm{C}$ (wrapped with aluminium foil). Samples were analyzed by measuring the absorbance of each sample by a microplate reader at a wavelength of $550 \mathrm{~nm}$ and calculate percent inhibition by following formula $\%$ inhibition $=$ control absorbance - test absorbance/control absorbance.

\section{RESULTS AND DISCUSSION}

\subsection{Chemistry}

Different substituted/ unsubsituted1, 2-diamino-benzene (10 mmol) and diethyl oxalate (12 $\mathrm{mmol}$ ) were stirred in $100 \mathrm{~mL}$ of EtOH. The reaction mixture was stirred for $4 \mathrm{~h}$ at reflux and the completion of the reaction was monitored on Thin Layer Chromatography (TLC). Finally, the reaction mixture was cooled, diluted with $200 \mathrm{~mL}$ of ice cold water and solid was filtered. The solid organic precipitate (55-85\% yield) was dried and this crude material was taken to the next step. The starting material 3a $(10 \mathrm{mmol})$ was taken in $50 \mathrm{~mL}$ ethanol solvent and allowed to stir for 10 minutes. A $6 \mathrm{~mL}$ mixture of $\mathrm{H}_{2} \mathrm{NNH}_{2} \cdot \mathrm{H}_{2} \mathrm{O}$ and $\mathrm{HCl}(1: 1)$ was prepared at 5 to $10^{\circ} \mathrm{C}$. This mixture was transferred to the RBF containing 3a solution at room temperature. The reaction mixture was refluxed for $4 \mathrm{~h}$. Progress of the reaction was monitored on TLC and after completion, the reaction mixture was poured on the ice water to get solid compound. After filtration and drying of the crude material (60-70\% yield), it was taken to the next step. A mixture of phenolic compound $\mathbf{5 a}(19.35 \mathrm{mmol})$ and dried $\mathrm{K}_{2} \mathrm{CO}_{3}(58 \mathrm{mmol})$ was added to 30 $\mathrm{mL}$ DMSO solvent. This mixture was stirred for one hour at room temperature. 4Fluorobenzaldehyde $6(16.13 \mathrm{mmol})$ was added to the above stirring solution and the reaction mixture was heated at $90^{\circ} \mathrm{C}$ for $16 \mathrm{~h}$. After completion of the reaction, the mixture was poured on crushed ice and extracted with ethyl acetate $(50 \mathrm{~mL} \times 3$ times). The organic layer was dried over sodium sulphate and then evaporated to get crude product. Pure product, pale yellow solid (65$75 \%$ yield) was obtained by silica gel column chromatography using hexane as solvent. Benzimidazole-2-carbohydrazide derivative $(0.1 \mathrm{~g}, 0.57 \mathrm{mmol})$ were added to $10 \mathrm{~mL} 2$ necked round bottom flask containing 4-phenoxybenzaldehyde derivatives $(0.51 \mathrm{mmol})$ and $0.5 \mathrm{~mL}$ acetic acid. Finally, the reaction mixture was stirred for $1-3 \mathrm{~h}$ at $80^{\circ} \mathrm{C}$. Progress of the reaction was monitored on TLC. After completion of reaction, precipitate was formed which on cooling 
and after filtration gave the desired product in $80-90 \%$ yield.

The IR, NMR and Mass spectroscopy are fully consistent with the structure.

\subsection{Anticancer Activity}

The synthesised Benzimidazole derivatives were evaluated for anticancer activity by Hep G2 Cell line (liver cancer cell line) with help of MTT assay. So it indicates that $1000 \mu \mathrm{g} / \mathrm{ml}$ shows maximum percentage of cell inhibition. The results of MTT assay of synthesized compound were compared with standard drug.

Table no 1. Effects of compound against Hep G2 Cell line (liver cancer cell line) by MTT assay

\begin{tabular}{|c|c|c|c|c|c|}
\hline $\begin{array}{l}\text { Sr. } \\
\text { no. }\end{array}$ & Sample & $\begin{array}{c}\text { ABS } \\
\text { T1 }\end{array}$ & \begin{tabular}{|c} 
Percentage \\
of cell \\
viability
\end{tabular} & $\begin{array}{l}\text { Percentage of } \\
\text { cell inhibition }\end{array}$ & IC 50 \\
\hline 1. & Control & 0.603 & -- & -- & -- \\
\hline 2. & $\begin{array}{c}\text { Sample } 1200 \\
\mu \mathrm{g} / \mathrm{ml}\end{array}$ & 0.553 & 91.71 & 8.29 & \multirow[t]{5}{*}{502.42} \\
\hline 3. & $400 \mu \mathrm{g} / \mathrm{ml}$ & 0.518 & 85.91 & 14.09 & \\
\hline 4. & $600 \mu \mathrm{g} / \mathrm{ml}$ & 0.502 & 83.26 & 16.74 & \\
\hline 5. & $800 \mu \mathrm{g} / \mathrm{ml}$ & 0.450 & 74.63 & 25.37 & \\
\hline 6. & $1000 \mu \mathrm{g} / \mathrm{ml}$ & 0.161 & 26.70 & 73.30 & \\
\hline
\end{tabular}

\section{CONCLUSION}

The properties of Benzimidazole derivatives for anticancer have been tested by percent cell viability through this analysis, it can be concluded that Benzimidazole derivatives may theoretically be transformed into anticancer agent that can enable future researchers to synthesis a collection of Benzimidazole derivatives comprising a broad range of substituent's in order to obtain new heterocyclic system to enhance anticancer action. 


\section{REFERENCES}

[1] Welsch, M. E.; Snyder, S. A.; Stockwell, B. R. Privileged Scaffolds for Library Design and Drug Discovery. Curr.Opin.Chem. Biol. (2010), 14, 347.

[2]Bansal, Y.; Silakari, O. The therapeutic journey of benzimidazoles.Bioorg.Med. Chem. $(2012) 20,6208$.

[3] Hernandez-Luis, F.; Hernandez-Campos, A.; Castillo, R.; Navarrete-Vazquez, G.; SoriaArteche, O.; Hernandez-Hernandez, M.; Yepez-Mulia, L. Synthesis and biological activity of 2-(trifluoromethyl)- 1H-benzimidazole derivatives against some protozoa and Tricheinellaspiralis. Eur. J. Med. Chem. (2010), 45, 3135.

[4] Khalil, A. M.; Berghot, M. A.; Gouda, M. A. Synthesis and study of some new 1,3isoinodoledione derivatives as potential antibacterial agents. Eur. J. Med. Chem. (2010), 45, 1552.

[5] Kamal, A.; Ponnampalli, S.; Vishnuvardhan, M. V. P. S.; Rao, M. P. N.; Mullagiri, K.; Nayak, V. L.; Chandrakant, B. Synthesis of imidazothiadiazole-benzimidazole conjugates as mitochondrial apoptosis inducers. MedChem Comm (2014), 5, 1644.

[6] Saour, K.; Lafta, D. Synthesis of New Benzimidazoles and Benzothiazole Disulfide Metal Complexes as G-quadruplex Binding Ligands. Anti-Cancer Agents Med. Chem. (2016), 16, 891.

[7] Zou, R.; Ayres, K. R.; Drach, J. C.; Townsend, L. B. Synthesis and Antiviral Evaluation of Certain Disubstituted Benzimidazole Ribonucleosides. J. Med. Chem. (1996), 39, 3477.

[8] Chassaing, C.; Berger, M.; Heckeroth, A.; Ilg, T.; Jaeger, M.; Kern, C.; Schmid, K.; Uphoff, M. Highly Water-Soluble Prodrugs of Anthelmintic Benzimidazole Carbamates: Synthesis, Pharmacodynamics, and Pharmacokinetics. J. Med. Chem. (2008), 51, 1111.

[9] Mavrova, A. T.; Yancheva, D.; Anastassova, N.; Anichina, K.; Zvezdanovic, J.; Djordjevic, A.; Markovic, D.; Smelcerovic, A. Synthesis, electronic properties, antioxidant and antibacterial activity of some new benzimidazoles. Bioorg.Med. Chem. (2015), 23, 6317. 
[10] Cereda, E.; Turconi, M.; Ezhaya, A.; Bellora, E.; Brambilla, A.; Pagani, F.; Donetti, A. Anti-secretory and 'anti-ulcer activities of some new 2-(2-pyridylmethyl-sulfinyl)benzimidazoles. Eur. J. Med. Chem. (1987), 22, 527.

[11] Wang, J.-L.; Zhang, J.; Zhou, Z.-M.; Li, Z.-H.; Xue, W.-Z.; Xu, D.; Hao, L.-P.; Han, X.-F.; Fei, F.; Liu, T.; Liang, A.-H. Design, synthesis and biological evaluation of 6-substituted aminocarbonylbenzimidazole derivatives as nonpeptidic angiotensin II AT1 receptor antagonists. Eur. J. Med. Chem. (2012), 49, 183.

[12] Hameed P, S.; Raichurkar, A.; Madhavapeddi, P.; Menasinakai, S.; Sharma, S.; Kaur, P.; Nandishaiah, R.; Panduga, V.; Reddy, J.; Sambandamurthy, V. K.; Sriram, D. Benzimidazoles: Novel Mycobacterial Gyrase Inhibitors from Scaffold Morphing. ACS Med. Chem. Lett. (2014), 5, 820. 